\title{
KAJIAN PEMASARAN TELUR AYAM DI KECAMATAN SUKOREJO KABUPATEN PASURUAN
}

\author{
Disusun Oleh: \\ Wenny Mamilianti,SP,MP \\ Dosen Fakultas Pertanian Universitas Yudharta Pasuruan
}

\begin{abstract}
ABSTRAK
Usaha ternak ayam petelur telah diupayakan untuk menjadi salah satu andalan usaha peternakan di Kabupaten Pasuruan, namun pengembangan berjalan lamban karena masih banyak peternak yang melakukan usaha secara tradisional dan terbatasnya informasi tentang pemasaran ayam petelur.Tujuan dari penelitian ini adalah untuk menganalisis saluran pemasaran telur, menganalisis margin pemasaran dan share harga ditingkat peternak atau produsen dan lembaga pemasaran serta pendekatan structure, conduct and market performance (S-C-P). Metode penelitian menggunakan metode studi kasus (case study). Pengambilan sampel lembaga pemasaran dilakukan secara total sampling, sedangkan sampel konsumen dilakukan secara accidental sampling. Analisa data berupa analisis secara deskriptif, analisis harga yang diterima produsen, analisis share keuntungan dan share biaya lembaga pemasaran, analisis margin pemasaran, pendekatan structure, conduct and market performance (S-C-P). Dari hasil penelitian dapat disimpulkan bahwa ada 2 tipe saluran pemasaran ayam petelur. Besarnya margin pemasaran yang diperoleh pada saluran I untuk pedagang besar Sidoarjo masing-masing yaitu Rp 700/kg, pedagang besar di Pasuruan Rp 500/kg, pedagang besar di Pandaan Rp 800/kg, dan saluran II untuk pedagang besar di Sukorejo sebesar Rp 600/kg. Share harga yang diterima peternak atau produsen masing-masing pedagang besar untuk saluran I yaitu pedagang besar di Sidoarjo 91,03\%, pedagang besar di Pasuruan 93,42\%, pedagang besar di Pandaan 89,74. Sedangkan untuk pendekatan struktur, perilaku dan penampilan pasar (S-C-P) menunjukkan masih belum efisiensinya saluran pemasaran telur.
\end{abstract}

\section{Kata kunci: Pemasaran telur ayam, Kecamatan Sukorejo Pasuruan}

\section{PENDAHULUAN}

Pembangunan di bidang peternakan merupakan bagian integral pembangunan pertanian khususnya dan pembangunan nasional pada umumnya yang bertujuan untuk meningkatkan produksi dan produktivitas ternak guna memenuhi protein hewani serta menciptakan lapangan kerja. Salah satu usaha yang dilakukan untuk meningkatkan produksi khususnya poduksi ayam petelur yaitu berupa telur konsumsi adalah pengembangan usaha peternakan ayam petelur yang bertujuan untuk menghasilkan telur dalam jangka waktu lama dan kontinyu. Pada masa mendatang usaha peternakan akan memberikan keuntungan bila ditingkatkan dari sekedar beternak (on farm bisnis) kearah usaha yang tinggi (off farm bisnis).

Seiring dengan semakin meningkatnya laju pertumbuhan penduduk dan semakin membaiknya tingkat pendapatan yang ditunjang pula dengan meningkatnya taraf pendidikan masyarakat, maka tingkat konsumsi penduduk terhadap produk-produk peternakan mengalami peningkatan. Salah satu produk peternakan yang banyak dikonsumsi oleh masyarakat luas salah satunya adalah telur ayam. Telur banyak dikonsumsi karena telur mengandung protein yang cukup tinggi sehingga baik untuk pertumbuhan dan kesehatan. Selain itu telur juga menjadi bahan baku industri makanan.

Usaha peternakan ayam petelur dapat berkembang dengan pesat karena 
usaha ini selain dapat dilakukan pada lahan yang tidak terlalu luas, juga karena ayam petelur memiliki kemampuan produksi telur yang cukup tinggi. Oleh karena itu hal utama yang diperhatikan oleh peternak adalah manajemen pengelolaan yang baik. Keberhasilan usaha peternakan selain tergantung dari sisi peternak dalam hal pengelolaan dan pada besar kecilnya biaya produksi yang sangat tergantung pada satu hal yaitu pemasaran produk yang telah dihasilkan. Pemasaran merupakan faktor yang sangat penting dalam menentukan keberhasilan dan kelangsungan hidup peternak karena apabila terlur yang diproduksi tidak dapat dipasarkan tentunya akan mengakibatkan kerugian bagi peternak dan usaha tersebut tidak dapat berjalan dengan lancar.

Salah satu bentuk usaha untuk mencapai tujuan dan sasaran di bidang pemasaran adalah dengan kegiatan pemilihan saluran pemasaran. Pemilihan saluran pemasaran diperlukan pertimbangan-pertimbangan yang menyangkut pertimbangan pasar, pertimbangan barang, dan pertimbangan perantara. Dengan pertimbangan tersebut saluran yang dipilih diharapkan saluran yang paling efektif. Karena suatu peternakan bilamana salah dalam memilih saluran pemasaran maka akan membawa akibat yang kurang menguntungkan bagi peternakan tersebut.

Dengan dipilihnya saluran pemasaran yang lebih efektif suatu peternakan dapat melakukan perbaikan strategi pemasaran yang sebelumnya sudah pernah diterapkan, bahkan dapat dipergunakan sebagai alternatif strategi pemasaran yang baru dimana nantinya dapat mewujudkan tujuan suatu peternakan yaitu dapat meningkatkan volume penjualan dari produk peternakan tersebut, sehingga menjadikan peternakan tersebut bisa tetap eksis, maju dan menang dalam dunia persaingan.

Berdasarkan uraian latar belakang di atas, maka dapat dirumuskan pertanyaan pokok dalam penelitian ini sebagai berikut:

1. Bagaimana saluran pemasaran telur ayam yang ada di Kecamatan Sukorejo ?

2. Berapa besar margin pemasaran, share harga di tingkat peternak atau produsen dan lembaga pemasaran ?

3. Bagaimana pendekatan struktur, perilaku dan penampilan pasar?

\section{TUJUAN PENELITIAN}

1. Menganalisis saluran pemasaran telur di Kecamatan Sukorejo

2. Menganalisis margin pemasaran, share harga di tingkat peternak atau produsen dan lembaga pemasaran, serta pendekatan struktur, perilaku dan penampilan pasar.

\section{METODOLOGI PENELITIAN}

\section{A. Lokasi dan Waktu Penelitian}

Penelitian dilaksanakan di

Kecamatan Sukorejo Kabupaten Pasuruan mulai 1 Juli sampai 1 Agustus 2009. Penentuan lokasi ini dilakukan secara sengaja (purposive) dengan pertimbangan bahwa dikecamatan ini sebagai sentra peternakan ayam petelur.

\section{B. Metode Penelitian}

Metode yang digunakan dalam penelitian ini yaitu metode studi kasus (cases study), yaitu penelitian tentang status subjek penelitian yang berkenaan dengan suatu fase spesifik atau khas dari keseluruhan personalitas (Nazir,1988). Dengan kata lain, penelitian dilakukan secara lebih mendalam mengenai kasus guna mempelajari secara intensif tentang latar belakang saat ini. Metode pengambilan 
responden lembaga pemasaran dilakukan secara total sampling, yaitu pengambilan sampel terhadap seluruh kelompok kunci (key group of cluster). Jadi semua kelompok atau rumpun dalam populasi itu diselidiki (Nazir, 1998). Sedangkan sampel untuk konsumen akhir dilakukan secara accidental sampling, yaitu pengambilan data pada individu atau kelompok yang dijumpai di suatu tempat. Jumlah responden pedagang besar ada 5 pedagang besar dan untuk pengecer 30 responden.

\section{Metode Analisa}

Proses analisis dalam penelitian dimulai dengan menelaah seluruh data yang tersedia dari berbagai sumber. Selanjutnya data yang diperoleh dianalisis dengan menggunakan deskriptif yaitu dengan tujuan menguraikan realita yang ditemukan dari hasil penelitian dilanjutkan dengan mengolah data kualitatif untuk mengetahui komponen biaya dengan menghitung semua biaya menggunakan analisis ekonomi meliputi :

1. Skema saluran distribusi produk ayam petelur.

2. Analisis margin pemasaran.

$$
\mathrm{MP}=\mathrm{Pr}-\mathrm{Pf}
$$

Keterangan :

$$
\begin{aligned}
& \text { MP : Margin pemasaran } \\
& \text { (RP.kg) } \\
& \text { Pr : Harga di tingkat } \\
& \text { konsumen (Rp/kg) } \\
& \text { Pf : Harga di tingkat } \\
& \text { produsen (Rp/kg) (Soekartawi, } \\
& \text { 1995) }
\end{aligned}
$$

3. Analisis Share harga yang diterima produsen.

$$
\text { Spf }=\overbrace{\operatorname{Pr}}{ }^{\mathrm{X}} \times 100 \%
$$

Keterangan :

$$
\text { Spf : Efisiensi }
$$

pemasaran (\%)
Pf : Harga di tingkat

produsen $(\mathrm{Rp} / \mathrm{kg})$

Pr : Harga di tingkat

konsumen $(\mathrm{Rp} / \mathrm{kg})$

(Sudiyono, 2002)

4.Analisis Share biaya pemasaran dan Share keuntungan lembaga pemasaran.

$$
\begin{array}{r}
\text { Ski }=\frac{(\mathrm{Kpi})}{(\mathrm{Pr}-\mathrm{Pf})} \times 100 \% \\
\text { Sbi }=\frac{(\mathrm{Bpi})}{(\mathrm{Pr}-\mathrm{Pf})} \times 100 \%
\end{array}
$$

Keterangan :

Ski : Share keuntungan

lembaga pemasaran ke-i (i

$=1)(\mathrm{Rp} / \mathrm{kg})$

Kpi : Keuntungan

lembaga pemasaran ke-i

( Rp/kg)

Sbi : Share biaya

pemasaran ke-i (Rp/kg)

Bpi : Biaya pemasaran

ke-i (Rp/kg)

Pf : Harga di tingkat

produsen $(\mathrm{Rp} / \mathrm{kg})$

Pr : Harga di tingkat

konsumen (Rp/kg)

Tolak ukur yang digunakan untuk mengukur efisiensi pemasaran adalah dengan melihat perbandingan share keuntungan dari masingmasing lembaga pemasaran yang terlibat dalam proses pemasaran dibandingkan dengan biaya pemasaran dari masing-masing lembaga pemasaran yang terlibat dengan kriteria sebagai berikut:

a. Apabila perbandingan share keuntungan dari masing-masing lembaga yang terlibat dalam proses pemasaran merata, maka sistem pemasarannya dikatakan efisien.

b. Apabila perbandingan share keuntungan dengan biaya pemasaran masing-masing yang terlibat dalam proses pemasaran 
merata dan cukup logis, maka sistem pemasarannya dikatakan efisien.
5. Analisis jalur pemasaran dengan pendekatan Structure-ConductPerformance (S-C-P).

\begin{tabular}{|c|c|c|c|}
\hline \multirow{2}{*}{$\begin{array}{l}\text { Model } \\
\text { Analisis }\end{array}$} & \multirow{2}{*}{$\begin{array}{l}\text { Indikator } \\
\text { Pengukuran }\end{array}$} & \multicolumn{2}{|c|}{ Penilaian } \\
\hline & & Efisien & $\begin{array}{c}\text { Tidak } \\
\text { Efisien }\end{array}$ \\
\hline Struktur & $\begin{array}{l}\text { Jumlah pedagang } \\
\text { Jumlah konsumen } \\
\text { J Kemudahan barang } \\
\text { untuk masuk pasar } \\
\text { > Konsentrasi pasar }\end{array}$ & $\begin{array}{l}>\text { Banyak } \\
>\text { Banyak } \\
>\text { Mudah } \\
>\text { Terkonsentrasi }\end{array}$ & $\begin{array}{l}>\text { Sedikit } \\
>\text { Sedikit } \\
>\text { Sulit } \\
\\
>\text { Tidak } \\
\quad \text { terkonsentrasi }\end{array}$ \\
\hline Perilaku & $\begin{array}{l}\text { P Penentuan kualitas } \\
\\
>\text { Praktek tidak jujur } \\
>\text { Persaingan antar } \\
\text { pedagang antar } \\
>\text { Pembentukan harga } \\
>\text { Koalisi promosi } \\
\text { pedagang } \\
\text { Kegiatan yang menyesatkan } \\
\text { y Persekongkolan } \\
\text { penetapan harga } \\
>\text { Biaya pemasaran }\end{array}$ & $\begin{aligned} & \text { Tidak } \\
& \text { ditentukan } \\
& \text { oleh/beberapa } \\
& \text { pedagang } \\
> & \text { Tidak ada } \\
> & \text { Sehat } \\
& \text { Standarisasi } \\
> & \text { Tidak ada } \\
> & \text { Tidak ada } \\
> & \text { Tidak ada } \\
& >\text { Sama }\end{aligned}$ & $\begin{aligned} & \text { Ditentukan } \\
& \text { oleh } \\
& \text { satu/beberapa } \\
& \text { pedagang } \\
&>\text { Ada } \\
&>\text { Tidak sehat } \\
&>\text { Normal } \\
&>\text { Ada } \\
&>\text { Ada } \\
&>\text { Ada } \\
&>\text { Berbeda }\end{aligned}$ \\
\hline Penampilan & $\begin{aligned} & \text { Distribusi margin } \\
& \text { pemasaran } \\
&> \text { Ketersediaan produk } \\
&> \text { Peningkatan } \\
& \text { penjualan } \\
&> \text { Share produsen } \\
&> \text { Penggunaan teknologi } \\
&> \text { Efisiensi sumber daya } \\
&> \text { Kebutuhan sesuai } \\
& \text { dengan investasi } \\
&> \text { Rasio output dan } \\
& \text { input } \\
&> \text { Dana promosi } \\
&\end{aligned}$ & $\begin{array}{l}>\text { Adil } \\
>\text { Terintegrasi } \\
>\text { Ada } \\
>\text { Besar } \\
>\text { Ada } \\
>\text { Terjadi } \\
>\text { Sesuai } \\
>\text { Tinggi } \\
>\text { Rasional }\end{array}$ & $\begin{array}{l}>\text { Tidak adil } \\
\\
>\text { Tidak } \\
\text { terintegrasi } \\
>\text { Tidak ada } \\
>\text { Kecil } \\
>\text { Tidak ada } \\
>\text { Tidak terjadi } \\
>\text { Tidak sesuai } \\
\\
>\text { Rendah } \\
>\text { Tidak rasional }\end{array}$ \\
\hline
\end{tabular}

\section{HASIL DAN PEMBAHASAN}

\section{Saluran Pemasaran}

Sebagai gambaran dari saluran pemasaran telur di Kecamatan Sukorejo Pasuruan dapat dilihat pada Gambar 1 yang menunjukkan bahwa saluran pemasaran telur di Kecamatan Sukorejo Pasuruan terdapat 2 jenis saluran pemasaran, yaitu :

I. Produsen $\rightarrow$ Pedagang besar $\longrightarrow$ Pengecer $\longrightarrow$ Konsumen 
II. Produsen $\longrightarrow$ Pedagang besar $\longrightarrow$ Konsumen

Saluran pemasaran yang pertama merupakan saluran distribusi tradisional dan masih banyak digunakan oleh produsen. Produsen hanya melayani dalam jumlah besar saja, tidak menjual kepada pengecer. Tipe ini menggunakan mutli midlement channel, yaitu perpindahan barang dari produsen sampai ke konsumen melalui berbagai perantara. Saluran pemasaran kedua menggunakan tipe single midlement channel, perpindahan barang dari produsen melalui satu perantara yaitu pedagang besar dan pengecer kepada konsumen (Wisaptiningsih, dkk. 1991).
Tipe saluran pemasaran kedua dikatakan cukup baik, jumlah lembaga pemasaran yang terlibat dalam saluran distribusi sedikit, sehingga harga yang diterima konsumen tidak terlalu besar. Jumlah pedagang besar banyak mempengaruhi volume penjualan, karena setiap pedagang besar mempunyai pelanggan sendiri-sendiri serta dipengaruhi oleh pendapatan dan selera konsumen terhadap telur. Volume penjualan telur pada masing-masing pedagang dipengaruhi oleh harga yang ditetapkan oleh masing-masing pedagang besar dan pedagang pengecer. Apabila jumlah konsumen bertambah, maka volume penjualan meningkat dengan asumsi harga yang relatif stabil.

\section{Margin Pemasaran}

Tabel 1. Rata-Rata Distribusi Margin Pemasaran Telur di Kecamatan Sukorejo per Juli 2009

\begin{tabular}{|c|c|c|c|c|}
\hline \multirow[t]{2}{*}{ Saluran Distribusi } & \multirow{2}{*}{$\begin{array}{l}\text { Harga ditingat } \\
\text { Produsen } \\
\text { (Rp/kg) }\end{array}$} & \multirow{2}{*}{$\begin{array}{l}\text { Harga ditingkat } \\
\text { Pedagang } \\
\text { (Rp/kg) }\end{array}$} & \multicolumn{2}{|c|}{ Margin Pemasaran } \\
\hline & & & $\begin{array}{l}\text { Total } \\
\text { (Rp/kg) }\end{array}$ & $\begin{array}{l}\text { Prosentase } \\
\text { (\%) }\end{array}$ \\
\hline \multirow{4}{*}{$\begin{array}{l}\text { I. Produsen } \longrightarrow \\
\text { Pedagang besar (Sidoarjo) } \longrightarrow \\
\text { Pengecer } \longrightarrow \\
\text { Konsumen }\end{array}$} & 7.100 & & & \\
\hline & & 7.400 & 300 & 42,86 \\
\hline & & 7.800 & 400 & 57,14 \\
\hline & & 15.200 & 700 & 100 \\
\hline \multirow{5}{*}{$\begin{array}{l}\text { Produsen } \longrightarrow \\
\text { Pedagang besar (Pasuruan) } \rightarrow \\
\text { Pengecer } \longrightarrow \\
\text { Konsumen }\end{array}$} & 7.100 & & & \\
\hline & & 7.200 & 100 & 20 \\
\hline & & 7.600 & 400 & 80 \\
\hline & & 14000 & 500 & 100 \\
\hline & 7800 & 14.000 & 500 & 100 \\
\hline \multirow{4}{*}{$\begin{array}{l}\text { Produsen } \longrightarrow \\
\text { Pedagang besar (Pandaan) } \longrightarrow \\
\text { Pengecer } \longrightarrow \\
\text { Konsumen }\end{array}$} & 7.000 & & & \\
\hline & & 7.300 & 300 & 37,50 \\
\hline & & 7.800 & 500 & 62,50 \\
\hline & & 15.100 & 800 & 100 \\
\hline \multirow{4}{*}{$\begin{array}{l}\text { Produsen } \longrightarrow \\
\text { Pedagang besar (Mojosari) } \longrightarrow \\
\text { Pengecer } \longrightarrow\end{array}$} & 7.000 & & & \\
\hline & & 7.300 & 300 & 42,86 \\
\hline & & 7.700 & 400 & 57,14 \\
\hline & & 15.000 & 700 & 100 \\
\hline \multirow{3}{*}{$\begin{array}{l}\text { II. Produsen } \longrightarrow \\
\text { Pedagang besar (Sukorejo) } \longrightarrow \\
\text { Konsumen }\end{array}$} & 7.050 & & & \\
\hline & & 7.650 & 600 & 100 \\
\hline & & 7.650 & 600 & 100 \\
\hline
\end{tabular}

Sumber : data sekunder diolah 
Margin pemasaran merupakan selisih antara harga yang harus dibayar konsumen akhir dengan harga yang diterima oleh produsen. Perhitungan margin pemasaran menggunakan cara yang dikemukakan oleh Sudiyono (2002), yaitu harga beli konsumen akhir dikurangi harga jual produsen. Margin pemasaran dapat mencerminkan efisiensi pemasaran, namun harus dilihat pula distribusi keuntungan maupun biaya yang dikeluarkan oleh lembaga pemasaran yang terlibat didalamnya. Perubahan margin pemasaran dipengaruhi oleh biaya pemasaran, tingkat keuntungan, jumlah permintaan, penawaran harga dan struktur, perilaku, penampilan pasar. Dengan kata lain, apabila terjadi perubahan komponen margin sebesar satu persen ditingkat produsen akan mengakibatkan perubahan komponen margin sebesar satu persen ditingkat lembaga pemasaran.

Besarnya margin pemasaran pada masing-masing lembaga pemasaran yang terlibat pada distribusi telur berbeda-beda. Hal ini tergantung dari banyaknya pedagang perantara yang terlibat dalam rantai pemasaran, sehingga menyebabkan semakin tinggi harga yang diterima oleh konsumen, akibatnya margin pemasaran adalah banyaknaya aktivitas yang dilakukan sehingga berpengaruh pada besarnya biaya yang dikeluarkan serta keuntungan yang diinginkan oleh masing-masing lemabaga pemasaran. Besarnya distribusi margin pemasaran yang diperoleh masing-masing lembaga pemasaran pada proses pemasaran telur dapat dilihat pada Tabel 1.
Tabel 1 menunjukkan bahwa distribusi margin pemasaran terbesar pada setiap saluran pemasaran pada pedagang perantara. Besarnya margin yang dihasilkan pada masing-masing saluran terlihat bahwa pada saluran pertama margin tertinggi ada pedagang pengecer dengan margin yang dihasilkan pedagang besar di Sidoarjo, Pasuruan, Mojosari sebesar Rp. 400/kg, pedagang besar di Pandan sebesar Rp.500/kg, sedangkan pada saluran kedua margin terbesar pada pedaang besar yaitu Rp. 600/kg dan merupakan saluran yang efisien dibandingkan dengan saluran yang pertama. Hal ini disebabkan rantai yang tidak terlalu panjang, dimana hanya ada pedagang perantara yang terlibat yaitu pedagang besar sehingga harga yang terjadi tidak terlalu besar. Semakin banyak perantara dalam pemasaran disetiap tingkat terjadi penentuan harga di setiap tingkat pun terjadi margin, hal ini menunjukkan adanya hubungan antara harga di tingkat produsen, harga di tingkat konsumen dan margin pemasaran.

\section{Share Harga di Tingkat Peternak (Farmer's Share)}

Share harga di tingkat peternak merupakan bagian harga yang diterima oleh peternak terhadap harga yang diterima oleh lembaga-lembaga pemasaran yang terlibat dalam pemasaran. Farmer's share juga dapat dijadikan faktor untuk melihat efisiensi dari saluran pemasaran telur. Besarnya share harga yang diterima produsen pada masing-masing saluran pemasaran yang terjadi di Kecamatan Sukorejo Pasuruan dapat dilihat pada Tabel 2. 
Tabel 2. Share Harga yang Diterima Produsen per Juli 2009

\begin{tabular}{|c|c|c|c|}
\hline Saluran Distribusi & $\begin{array}{l}\text { Harga ditingat } \\
\text { Produsen }(\mathrm{Rp} / \mathrm{kg})\end{array}$ & $\begin{array}{l}\text { Harga ditingkat } \\
\text { Pedagang (Rp/kg) }\end{array}$ & Share harga (\%) \\
\hline 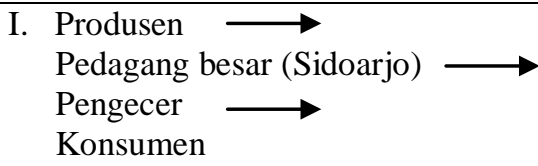 & 7.100 & 7.800 & 91,03 \\
\hline $\begin{array}{l}\text { Produsen } \longrightarrow \\
\text { Pedagang besar (Pasuruan) } \rightarrow \\
\text { Pengecer } \longrightarrow \\
\text { Konsumen }\end{array}$ & 7.100 & 7.600 & 93,42 \\
\hline $\begin{array}{l}\text { Produsen } \longrightarrow \\
\text { Pedagang besar (Pandaan) } \longrightarrow \\
\text { Pengecer } \longrightarrow \\
\text { Konsumen }\end{array}$ & 7.000 & 7.600 & 92,11 \\
\hline $\begin{array}{l}\text { Produsen } \longrightarrow \\
\text { Pedagang besar (Mojosari) } \longrightarrow \\
\text { Pengecer } \longrightarrow \\
\text { Konsumen }\end{array}$ & 7.000 & 7.700 & 90,91 \\
\hline $\begin{array}{l}\text { II. Produsen } \longrightarrow \\
\text { Pedagang besar (Sukorejo) } \longrightarrow \\
\text { Konsumen }\end{array}$ & 7.050 & 7.650 & 92,16 \\
\hline
\end{tabular}

Tabel 2 diketahui bahwa pada proses pemasaran yang dilakukan pada saluran pertama share harga yang diterima produsen dari pedagang besar di Sidoarjo sebesar 91,03\%, pedagang besar Pandaan 62,11\%, pedagang besar Pasuruan sebesar 63,12\% dan pedagang besar Mojosari 90,91\%, sedangkan saluran kedua sebesar 92,16\%. Besarnya share harga yang diterima oleh peternak atau produsen dapat dikatakan layak, hal ini sesuai dengan pernyataan Downey dan Erickson (1992) yang menyatakan bahwa pemasaran hasil pertanian ditinjau dari bagian harga yang diterima petani produsen dikatakan efisien apabila harga jual produsen lebih dari 40\% dari harga di tingkat konsumen. Sudiyono (2002) menyebutkan bahwa jika harga yang diterima produsen lebih rendah dari 50\% maka dapat dikatakan bahwa struktur pasar dan informasi pasar yang terjadi belum sempurna, keadaan demikian menunjukkan sistem pemasaran terkait belum bisa dikatakan efisien.

Tingginya share harga yang diterima produsen atau peternak tidak mengindikasikan bahwa harga yang diterima telah memadai, tetapi lebih dikarenakan relatif pendeknya saluran pemasaran yang terjadi pada rendahnya aktifitas atau fungsi pemasaran yang dijalankan. Sehingga perlu diperhatikan merata atau tidaknya margin yang terjadi serta share biaya dan keuntungan yang diterima antara lembaga pemasaran yang terlibat. Hal tersebut sesuai dengan pendapat Wedastra (1999) bahwa efisiensi pemasaran merupakan kemampuan produsen bersama lembaga pemasarannya dalam hal produksi atau komoditi kepada konsumen dengan harga yang wajar tanpa mengorbankan berbagai pihak 
yang terlibat dalam saluran pemasaran. Dengan hanya memperhatikan hasil share harga yang diterima produsen berdasar pada teori yang disebutkan dapat dikatakan bahwa pemasaran yang terjadi pada kedua saluran yang ada adalah efisien. Tetapi hanya dengan memperhatikan share harga yang diterima produsen belum bisa mengindikasikan bahwa pemasaran telur yang terjadi pada Kecamatan Sukorejo Pasuruan dapat dikatakan efisien secara keseluruhan.

\section{Share Biaya dan Share Keuntungan Lemabaga Pemasaran}

\section{Tabel 3. Rata-Rata Share Biaya dan Share Keuntungan Lembaga Pemasaran Telur per Juli 2009}

\begin{tabular}{|c|c|c|c|c|c|c|}
\hline \multirow[t]{2}{*}{ Saluran Distribusi } & \multicolumn{2}{|c|}{ Biaya (Rp/kg) } & \multirow{2}{*}{$\begin{array}{l}\text { Share } \\
(\%)\end{array}$} & \multicolumn{2}{|c|}{ Keuntungan (Rp/kg) } & \multirow{2}{*}{$\begin{array}{l}\text { Share } \\
(\%)\end{array}$} \\
\hline & Produsen & $\begin{array}{l}\text { Pedagang } \\
\text { Perantara }\end{array}$ & & Produsen & $\begin{array}{l}\text { Pedagang } \\
\text { Perantara }\end{array}$ & \\
\hline 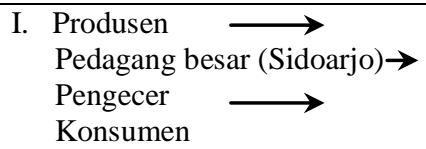 & 41,10 & $\begin{array}{l}47,92 \\
7,79\end{array}$ & $\begin{array}{l}5,87 \\
6,85\end{array}$ & 658,90 & $\begin{array}{l}652,08 \\
692,21\end{array}$ & $\begin{array}{l}94,13 \\
93,15 \\
98,89\end{array}$ \\
\hline $\begin{array}{l}\text { Produsen } \longrightarrow \\
\text { Pedagang besar (Pasuruan) } \rightarrow \\
\text { Pengecer } \\
\text { Konsumen }\end{array}$ & 41,10 & $\begin{array}{l}55,81 \\
36,89\end{array}$ & $\begin{array}{c}8,22 \\
11,16 \\
7,38\end{array}$ & 458,90 & $\begin{array}{l}444,19 \\
463,11\end{array}$ & $\begin{array}{l}91,78 \\
88,84 \\
92,62\end{array}$ \\
\hline $\begin{array}{l}\text { Produsen } \longrightarrow \\
\text { Pedagang besar (Pandaan) } \rightarrow \\
\text { Pengecer } \\
\text { Konsumen }\end{array}$ & 41,10 & $\begin{array}{l}45,83 \\
34,42\end{array}$ & $\begin{array}{l}5,14 \\
5,73 \\
4,30\end{array}$ & 758,90 & $\begin{array}{l}744,17 \\
765,58\end{array}$ & $\begin{array}{l}94,86 \\
93,02 \\
95,70\end{array}$ \\
\hline $\begin{array}{l}\text { Produsen } \longrightarrow \\
\text { Pedagang besar (Mojosari) } \rightarrow \\
\text { Pengecer } \\
\text { Konsumen }\end{array}$ & 41,10 & $\begin{array}{l}46,62 \\
36,88\end{array}$ & $\begin{array}{l}5,87 \\
6,66 \\
5,27\end{array}$ & 658,9 & $\begin{array}{l}653,38 \\
663,12\end{array}$ & $\begin{array}{l}94,13 \\
93,34 \\
94,73\end{array}$ \\
\hline $\begin{array}{l}\text { II. Produsen } \longrightarrow \\
\text { Pedagang besar (Sukorejoł } \\
\text { Konsumen }\end{array}$ & 41,10 & 65,4 & $\begin{array}{l}6,85 \\
10,9\end{array}$ & 558,9 & 534,6 & $\begin{array}{l}93,15 \\
89,10\end{array}$ \\
\hline
\end{tabular}

Sumber : data sekunder diolah

Share biaya dan share keuntungan juga digunakan untuk mengetahui tingakt efisiensi saluran distribusi telur diantara lembaga pemasaran yang terlibat. Share harga dan share keuntungan lembaga pemasaran dilakukan untuk mengetahui sampai seberapa besar biaya yang dikeluarkan dalam upaya mencapai tingkat keuntungan yang diinginkan oleh masing-masing lembaga pemasaran. Tingakat share biaya dan share keuntungan lembaga pemasaran dalam proses distribusi telur yang terjadi pada Bakalan Farm dapat dilihat pada Tabel 3.
Tabel 3 menjelaskan bahwa share biaya terbesar terdapat pada pedagang besar dan share keuntungan terbesar terdapat pada pedagang pengecer, hal ini sesuai dengan pendapat Masyrofie (1994) yang menyatakan bahwa banyak sedikitnya aktifitas fungsi pemasaran yang dilaksanakan akan mempengaruhi besar kecilnya biaya pemasaran yang dikeluarkan oleh pelaku pemasaran. Saluran kedua, dimana di Sukorejo hanya melibatkan satu pedagang perantara yaitu pedagang besar diperoleh hasil share keuntungan sebeasr $89,10 \%$. Hal tersesut berkaitan 
dengan saluran distribusi di Sukorejo menjual telur kepada peadagang besar yang langsung menjualnya kepada konsumen, sehingga harga yang berlaku di produsen lebih tinggi dibanding jika penjualan pada pedagang besar lainnya. Hal tersebut dapat diketahui dari share biaya dan keuntungan pada saluran tersebut. Berdasarkan saluran yang terjadi, maka pada saluran kedua lebih efisien dibandingkan saluran yang pertama, karena salah satu tolak ukur yang digunakan untuk mengukur efisiensi pemasaran adalah dengan melihat perbandingan share biaya dan keuntungan dari masing-masing lembaga pemasaran yang terlibat dalam proses pemasaran. Adapun kriteria yang digunakan yaitu jika share biaya dan keuntungan dari masing-masing lembaga yang terlibat dalam proses pemasaran merata dan cukup logis maka sistem pemasarannya dikatakan efisien.

\section{Analisis Kinerja Saluran Distribusi dengan Pendekatan Struktur, Perilaku dan Penampilan Pasar (Structure, Conduct and Market Performance)}

Analisis struktur, perilaku dan penampilan pasar dilakukan secara deskriptif berdasarkan kualifikasi pada Tabel 4.16. dengan tujuan mempermudah proses analisis. Kualifikasi yang dipakai peneliti mengadopsi pendapat Soekartawi (1993), Abbot (1981) dan Sudiyono (2000) dengan memberi batasan dan aspek yang perlu diperhatikan dalam pendekatan struktur, perilaku dan penampilan, yaitu:

\section{Struktur Pasar}

1. Jumlah pedagang dan pembeli yang relatif banyak. Jumlah pedagang banyak hal ini sangat menguntungkan bagi konsumen karena konsumen bisa membandingkan harga di tingkat pedagang. Di Sukorejo memiliki 5 pedagang besar yang letaknya terpisah, yaitu di Sidoarjo, Sukorejo sendiri, Pasuruan, Pandaan dan Mojosari. Masing-masing pedagang besar tersebut juga memiliki pengecer atau langsung konsumen.

2. Pasar cenderung terkonsentrasi di wilayah Sidoarjo, hal ini dapat diamati pada lokasi pedagang dan konsumen terbanyak. Produsen cenderung kurang memperhatikan wilayah selain Sidoarjo karena volume penjualan terbesar produsen berada di Sidoarjo. Perluasan wilayah pemasaran sangat diperlukan untuk pengembangan peningkatan volume penjualan.

\section{Perilaku Pasar}

1. Kualitas produk tidak ditentukan oleh satu atau bebrapa pedagang besar dan pedagang pengecer. Pedagang besar dan pengecer serta konsumen menginginkan produk yang berkualitas tanpa memperhatikan harga produk.

2. Harga produk ditentukan secara tersendiri oleh masing-masing pedagang sesuai denga keuntungan yang diharapkan oleh pedagang besar dan pengecer. Dalam hal ini pedagang menggunakan metode mark up seperti yang telah dikemukakan oleh Gitosudarmo(1994).

Menurut Sutawi (2002) ada beberapa faktor yang mempengaruhi kebebasan untuk menerapkan harga, antara lain :

a. Persaingan, semakin banyak pesaing, maka kebebasan menentukan harga semakin terbatas. 
b. Reputasi, reputasi produsen atau lembaga pemasaran mempengaruhi tinggi rendahnya harga produk.

c. Kondisi lingkungan, apabila perusahaan ingin menetapkan harga, maka perusahaan tersebut harus dapat membuat suasana tempat penjualannya berbeda dengan tempat penjualan pesaing.

d. Bauran produk, daur hidup produk dan permintaan konsumen.

3. Tidak kolusi antar pedagang, persaingan usaha sehat antar pedagang dan praktek kejujuran para pedagang menjadikan nilai tambah kredibilitas dihati konsumen baik dalam penetapan harga jual maupun kegiatan pemasaran lainnya.

4. Biaya pemasaran tidak sama besarnya karena volume penjualan tiap lembaga pemasaran dan jarak lokasi antar pedagang berbeda. Soekartawi (1993) menyatakan besarnya biaya pemasaran berbeda satu dengan lain, hal ini disebabkan oleh efektifitas pemasaran yang berlaku.

\section{Penampilan Pasar}

1. Nilai share yang diterima produsen tergolong adil dan rasional dibandingkan dengan share yang diterima lembaga pemasaran. Sudiyono (2002) berpendapat bahwa bila harga per unit produk tinggi di tingkat konsumen, maka harga per unit produk di tingkat lembaga pemasaran juga tinggi, sehingga dapat disebut tidak efesien, begitu juga sebaliknya.

2. Margin pemasaran dan distribusi margin pemasaran yang diketahui adil dan wajar. Perbedaan margin dan distribusi pemasaran pada lembaga pemasaran terjadi karena perbedaan kreatifitas lembaga pemasaran dalam melakukan promosi dan tujuan usaha serta kepandaian memuaskan konsumen. Margin pemasaran ialah selisih antara harga yang harus dibayar konsumen dengan harga yang diterima produsen. Margin pemasaran ini diperlukan untuk menutup biaya pemasaran dan untuk memperoleh laba yang direncanakan (Soekartawi, 1993).

3. Produk tersedia setiap saat, karena produsen setiap hari menjual telur kepada para pedagang, selanjutnya pedagang menjualnya kepada konsumen. Sehingga konsumen dengan mudah bisa mendapatkan produk tersebut. Menurut Sutawi (2002) kombinasi produk tepat dapat menunjang kemampuan produsen untuk mencapai tujuan perusahaan.

4. pertumbuhan pasar dan peningkatan volume penjualan cenderung berfluktuasi. Naiknya tingakat harga terjadi pada saat-saat hari besar keagamaan dan pada saat upacara adat.

5. penggunaan teknologi tinggi pada lembaga pemasaran belum digunakan karena lembaga pemasaran tidak melakukan perubahan dan penambahan yang dapt menambah nilai guna dari produk telur.

6. dana promosi yang kurang pada produsen, sehingga volume penjualan cenderung tidak meningkat bahkan tidak ada pada lembaga pemasaran. Besarnya dana promosi harus diiringi degan peningkatan volume penjualan untuk mengurangi resiko kerugian. Keadaan struktur, perilaku dan penampilan pasar tidak selamanya akan selalu seperti kondisi yang 
sekarang. Seiring berjalannya usaha, kondisi ini akan berubah menjadi efisien atau sebaliknya menjadi tidak efisien. Hal ini terjadi karena sifat pasar yang tidak menentu.

Dari analisis yang digunakan yaitu margin pemasaran antar lembaga pemasaran dan share biaya dan keuntungan tiap lembaga pemasaran yang telibat menunjukkan variasi yang merata maka dapat dikatakan bawa saluran distribusi telur di Sukorejo adalah efisien. Sedangkan berdasarkan analisis struktur, perilaku dan penampilan pasar, sebagian besar sudah efisien walupun masih terdapta beberapa hal yang belum efisien.

\section{DAFTAR PUSTAKA}

Abbot. Mahekam. 1981. Agriculture Economic and Marketing in The Tropics Longman Group Ltd. Essex.

Anonymous. 1998. Isa Brown Parent Stock Management. Guide. Prancis.

Abidin, Z. 2003. Meningkatkan Produktifitas Ayam Petelur. PT. Agromedia. Jakarta.

Chandra, G. 2002. Strategi dan Program Pemasaran. Andi. Jakarta.

Djannah, D. 1998. Beternak Ayam. CV. Yasaguna. Yogyakarta.

Downey W.D dan Erickson Steven, P. 1992. Manajemen Agribisnis. Edisi Kedua. Alih bahasa oleh Rochidayat Ganda, S. Erlangga. Jakarta.

Gitosudarmo, H. I. 1994. Manajemen Pemasaran. Edisi Pertama. BPFE. Yogyakarta.

Hanafiah, A.M dan Saefuddin, A. 1986.

Tata Niaga Hasil Perikanan. Universitas Indonesia (UIPress). Jakarta.
Indarto, P. 1990. Beternak Unggas

Berhasil. Armico. Bandung.

Kotler, P. 1997. Manajemen

Pemasaran. Terjemahan oleh Hendra Teguh dan Roni, A. Rusli. Edisi Bahasa Indonesia. Prenhallindo. Jakarta.

Kusnasi. 1999. Akuntansi Biaya (Tradisional dan Modern). Fakultas Ekonomi UI. Penebar Swadaya. Jakarta.

Martin, Stephan. 1989. Industrial Economic, Economic Analysis and Public olicy. Macmilan Publishing Company. New York.

Mubyarto. 1989. Pengantar Ekonomi Pertania. LP2ES. Jakarta.

Murtidjo, B.A. 1990. Pedoman Beternak Ayam Petelur.Kanisius Yogyakarta.

Masyrofie. 1994. Pemasaran Hasil

Pertanian. Jurusan Sosial ekonomi Fakultas Pertanian Universitas Brawijaya. Malang.

Mulyadi. 1999. Akuntansi Biaya. Aditya Media. Yogyakarta.

Nazir M. 1998. Metode Penelitian. Yudhistira. Jakarta.

Nazaruddin dan Viviani, T.J. 1991. Petunjuk Praktis Usaha Peternakan. PD. Mahkota. Jakarta.

Nitisemito, A.S. 1984. Pembelanjaan Perusahaan. Ghalia Indonesia. Jakarta.

. 1991. Marketing. Ghalia Indonesia. Jakarta.

Rasyaf M. 1996. Memasarkan Hasil Peternakan. Swadaya. Jakarta.

2001. Manajemen Peternakan Ayam Petelur. Penebar Swadaya. Jakarta.

Swastha, B dan Irawan. 1990. Manajemen Pemasaran. Modern. Liberty. Yogyakarta. 
Soekartawi. 1995. Analisa Usaha Tani. UI Press. Jakarta.

Stanton, W.J. 1996. Prinsip Pemasaran. Jilid I dan II. Terjemahan Y. Laramto. Erlangga. Jakarta.

Saladdi D. 1994. Dasar-dasar Manajemen Pemasaran. Mander Maju. Bandung.

Sudaryani, T. dan Santoso, H. 2001.

Pemeliharaan Ayam Ras Petelur di Kandang Baterai. Penebar Swadaya. Jakarta.

Sigit, S. 2002. Pemasaran Praktis. Edisi 3. BPFE. Yogyakarta.

Sudiyono, A. 2002. Pemasaran Pertania. UMM Press. Malang.

Sutawi. 2002. Manajemen Agribisnis. UMM Press. Malang.
Tjiptoadinugroho, R. 1999. Neraca Perusahaan, Membaca, dan Membahas. Pradya Paramita. Jakarta.

Wasis. 1986. Pengantar Ekonomi Perusahaan. Alumni. Bandung.

Winardi. 1990. Kapita Selekta Ekonomi Perusahaan. Nova. Bandung.

Wisaptiningsih, U., Noegroho, dan Fanani, Z. 1991. Tataniaga Ternak. Fakultas Peternakan Universitas Brawijaya. Malang.

Widodo, W., Noegroho., Fanani, Z. Dan Fatimah, S. 1993. Tataniaga Hasil Ternak di Indonesia. Fakultas Peternakan Universitas Brawijaya. Malang. 
